\title{
Integrative Gastroenterology and Hepatology
}

\section{Expression of Angiogenin is inversely correlated to Progression of Gastric Tumors}

\author{
Al-sarraf $M^{1 \#}$, Xiao-Tao $H^{2 \#}$, Zhi-qiang $Z^{3}$, Bin $L^{3}$, Jing $L^{4}$ and Yun-Xia $W^{1 *}$ \\ ${ }^{1}$ Department of Pharmacology, Pharmacy School of Tongji Medical College of Huazhong University of Science and \\ Technology, Wuhan, China \\ ${ }^{2}$ Department of Integrative Traditional Chinese Medicine and Western Medicine, Women and Children's Hospital of \\ Hubei Province, Tongji Medical College of Huazhong University of Science and Technology, Wuhan, Hubei, China \\ ${ }^{3}$ Department of Pathology, Hubei General Hospital of Chinese People's Armed Police Forces, Wuhan, China \\ ${ }^{4}$ Department of Emergency, Hubei General Hospital of Chinese People's Armed Police Forces, Wuhan, China \\ "Equal contribution
}

*Correspondence: Wu Yun-Xia, Department of Pharmacology, Pharmacy School of Tongji Medical College of Huazhong University of Science and Technology, Hankou Aviation Road 13, Wuhan City, Hubei Province, 430030, China, Tel: 86-27-13317185799; Fax: 86-27-83692732; E-mail: wuyunxia@hust.edu.cn

Received: Jan 29, 2019; Accepted: Mar 27, 2019; Published: Apr 01, 2019

\begin{abstract}
Objective: Angiogenin (ANG) is upregulated in a variety of cancers including those of prostate, cervix, pancreas, liver, oral cavity, skin, and etc., however, the role of ANG in gastric cancer has not been fully elucidated yet. We use Tissue Microarray (TMA) to examine ANG expression to investigate the role of ANG in the progression of gastric cancer.

Method: Immunohistochemistry was used to evaluate ANG expression in TMA with 208 spots from 104 patients diagnosed with gastric cancer and the corresponding adjacent tissue.

Results: In normal adjacent tissue, ANG was expressed mainly in cytoplasm at basal gland of the gastric mucus where gastric stem cells are reserved, and also sparsely expressed in the nucleus of gastric mucosal gland cells at isthmus where gastric stem cells are gathered. In cancer tissues, ANG was very sparsely expressed in the nucleus of gastric glandular cells. ANG expression in the cytoplasm was found to be significantly associated with pathological types $(p<0.001)$ and malignancy $(p<0.001)$. ANG expression in the nucleus was inversely correlated with malignancy $(p=0.019)$, differentiation status $(p<0.001)$, and tumor stage $(p=0.048)$.
\end{abstract}

Conclusion: ANG might play an important role in gastric cancer development.

\section{Introduction}

Angiogenin (ANG) was originally isolated as the most potent angiogenic protein based on chicken embryo Chorioallantoic Membrane (CAM) angiogenesis assay [1]. ANG has a dual role in cancer progression: it stimulates cancer cell proliferation as well as mediates tumor angiogenesis. ANG may also have a dual role in amyotrophic lateral sclerosis (ALS) by regulating both endothelial cells and motor neurons [2]. More recently, ANG has been shown to play a role in stem cell regulation by promoting hematopoietic regeneration through dichotomous regulation of stem cell quiescence and progenitor cell proliferation [3]. ANG was reported to be upregulated in a variety of cancers including prostate, cervical, pancreatic, liver, oral and skin cancer. It has been suggested that angiogenin may be clinically useful in diagnosis, prognosis, and therapy of cancers [4-9]. Here we report that ANG expression is downregulated in gastric cancers. We examined ANG expression in a tissue microarray containing 104 gastric cancer tissues and with the same number of corresponding normal adjacent tissues, and found that ANG expression was inversely correlated with gastric cancer. 


\section{Methods}

\section{Tissue sampling}

The micro tissue array (MTA) was bought from Xi'an Elena Biotechnology Co., Ltd, China with 208 points from 104 gastric cancer patients. For each patient, a carcinoma tissue and an adjacent tissue (AT) were selected. The 104 patients are composed of 40 cardia cancer, 4 fundus cancer, 32 gastric body cancer, and 28 antrum cancer. Pathological diagnosis was made by hematoxylin and eosin staining, and the evaluation of the tissue staining was assessed according to the general role of clinical and histopathological studies for stomach disease in China.

\section{ANG immunohistochemistry staining}

MTA tissues were treated with xylene for 20, 15, 10 minutes respectively to dewax, and then washed with $100 \%, 95 \%, 90 \%, 80 \%, 70 \%$ ethanol, respectively, for 5 minutes each, to dehydrate, and then washed with phosphate buffered saline(PBS) 3 times for 5 minutes each. Endogenous peroxidase was blocked with $3 \%$ hydrogen peroxidase solution in methanol for 15 minutes. After heat retrieval in citric acid $\left(0.01 \mathrm{M}, \mathrm{P}^{\mathrm{H}}=6.1\right)$, the MTA was incubated with $5 \%$ bovine serum albumin (BSA) at room temperature for $40 \mathrm{~min}$, incubated with ANG monoclonal antibody $26-2 \mathrm{~F}(10 \mu \mathrm{g} / \mathrm{ml})$ at $4^{\circ} \mathrm{C}$ overnight and room temperature for 1 hour. Negative control was normal goat IgG $(10 \mu \mathrm{g} / \mathrm{ml})$. After washed three times with PBS, HRP conjugate of second antibody (1:1000) was added and incubated for 30 minutes at $37^{\circ} \mathrm{C}$. The MTA was visualized by 3, $3^{\prime}$-diaminobenzidine (DAB) and counterstained by hematoxylin.

\section{Evaluation of ANG immunostaining}

The evaluation of ANG expression was performed under routine histological methods [10]. Each spot of the slide was examined under a microscope at low magnification (40x) to identify the strongest ANG expression according to color and area. Then, five microscopic areas at 400 fold magnification were chosen for analysis. ANG was detected in both cytoplasm and nucleus in glandular cells but not in mesenchymal cells at all. ANG staining in both nucleus and cytoplasm were categorized as 3 grades in color corresponding to $(-/ 0)$ negative, (+/1) weak expression, $(++/ 2)$ strong expression (Figure 1$)$, and 6 grades in positive area corresponding to $(0, \leq 1 \%),(1,1 \% \sim 5 \%),(2$, $6 \% \sim 10 \%),(3,11 \% \sim 25 \%),(4,26 \% \sim 50 \%),(5,50 \%)$. A total score was obtained by multiplying color and area grades, and recorded as immunoreactivity score (IS) that are defined as: negative (-), score $=0$; weak expression (+), score = 1-4; moderate expression $(++)$, score $=5-8$; and strong expression $(+++)$, score $=9-12$.

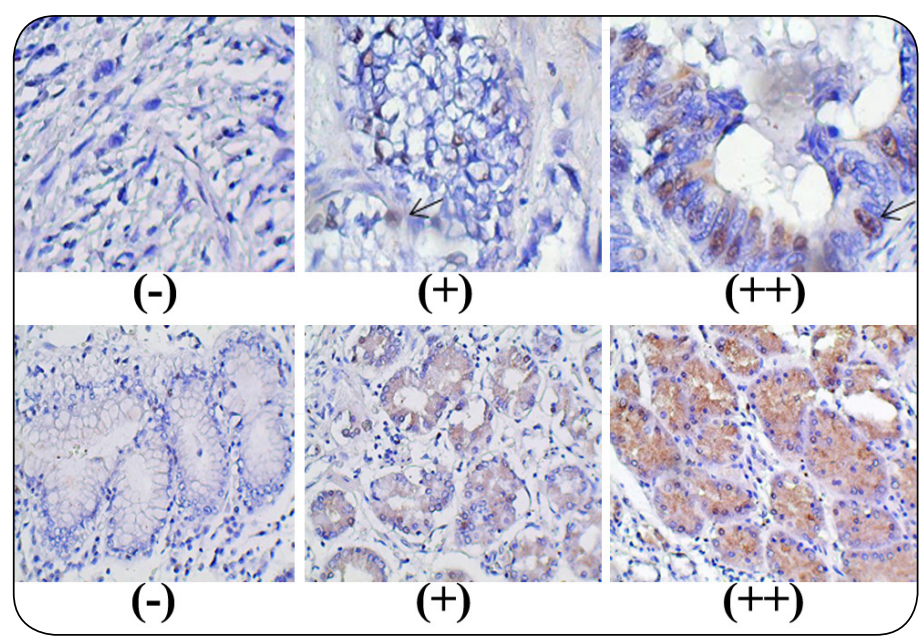

Figure 1: Grading of representative staining of nuclear and cytoplasmic ANG. The upper panel shows nuclear

ANG staining at $400 X$, the bottom panel shows cytoplasmic ANG staining at $200 \mathrm{X}$.

\section{Statistical analysis}

Chi-square test and $t$-test were used to evaluate the difference; all statistical calculations were carried out using the SigmaPlot 12.5 statistical software (copyright 2011 systat software, Germany). It is considered significant when $P$ value is $<0.05$.

\section{Results}

\section{Cancer characteristic and histological examination}

The demographic and clinical characteristic of the patients as well as the tumor and adjacent tissues are described in table 1 . The patients were 77 men and 27 woman, had a mean age of 60.3 years ranging from 33 to 81 . The main three areas of stomach that were affected by cancer were cardia, body/fundus and antrum, including gastric cardia $(n=40)$, gastric body/fundus $(n=36)$ and antrum $(n=28)$. The histological diagnosis were adenocarcinoma $(n=102)$, singlet-ring cell carcinoma $(n=1)$, and squamous cell carcinoma $(n=1)$. The adjacent tissues were normal gastric mucosa $(n=42)$, chronic gastritis $(n=59)$, and atrophic gastritis $(n=3)$.

\section{ANG expression in malignant tumor tissue, adjacent normal gastric tissue and different histological pathology type}

In adjacent normal gastric tissue, ANG was expressed mainly in the cytoplasm of gastric basal gland or in the nucleus at isthmus, but not in mesenchymal cells at all. 
In cancer tissues, ANG was very sparsely expressed in nucleus as shown in figure 2. The expression score of nuclear and cytoplasmic ANG was evaluated separately and showed in tables 2 and 3, respectively. There was a significant difference both in the nucleus $(P=0.019)$ and in the cytoplasm $(P<0.001)$ in term of ANG expression between cancer and adjacent normal tissues, both showing a decreased expression in cancers as compared with normal gastric glandular tissues. These data indicate that ANG expression is negatively related with gastric malignancy. There was a progressive decrease in the cytoplasmic ANG expression score in the continuum of gastric tissue from normal gland to chronic gastritis, atrophic gastritis, and cancer, which was $4.68 \pm 2.90,3.86$ $\pm 3.31,3.33 \pm 5.77$ and $0.75 \pm 1.24$, respectively, indicating that ANG expression in the cytoplasm is negative related with gastric cancer progression $(P<0.001)$. It is notable that no correlation of ANG expression in the nucleus with the gastric cancer progression was observed $(P=0.084)$.

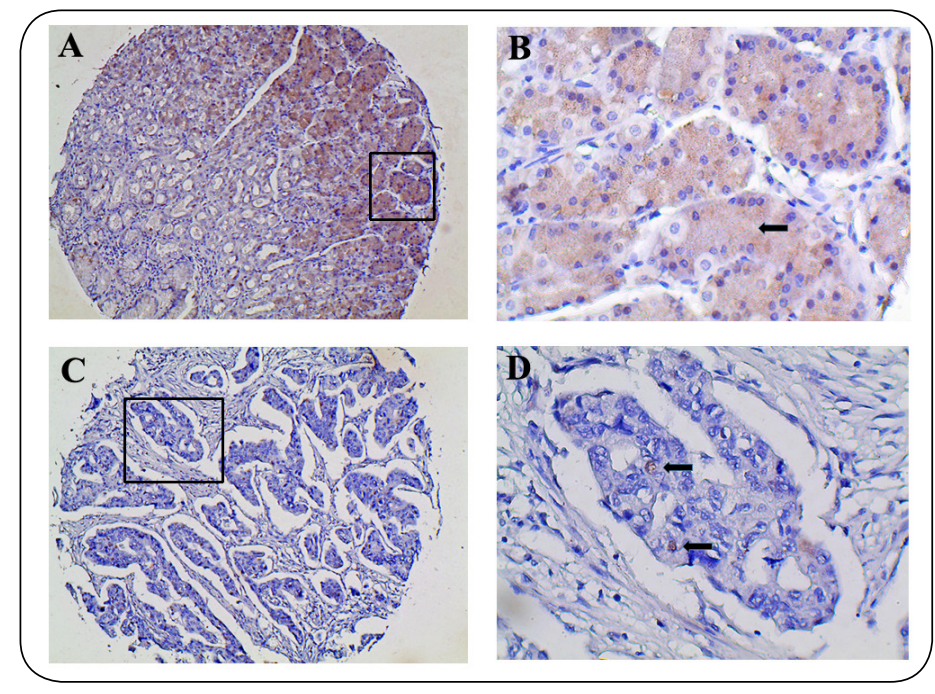

Figure 2: Representative images of ANG stating in adjacent normal gastric tissues ( $A$ and $B, 40 X$ and 400 $X$, respectively) and gastric cancer tissue ( $C$ and $D, 40 X$ and $400 X$, respectively). Arrows indicate positive ANG staining.

\section{ANG expression in different types of carcinoma}

The expression of ANG in gastric adenocarcinoma, signet-ring carcinoma, and squamous carcinoma was all low and mainly distributed in the nucleus, as shown in figure 3, indicating that ANG expression is universally lower in gastric cancers regardless of carcinoma types.

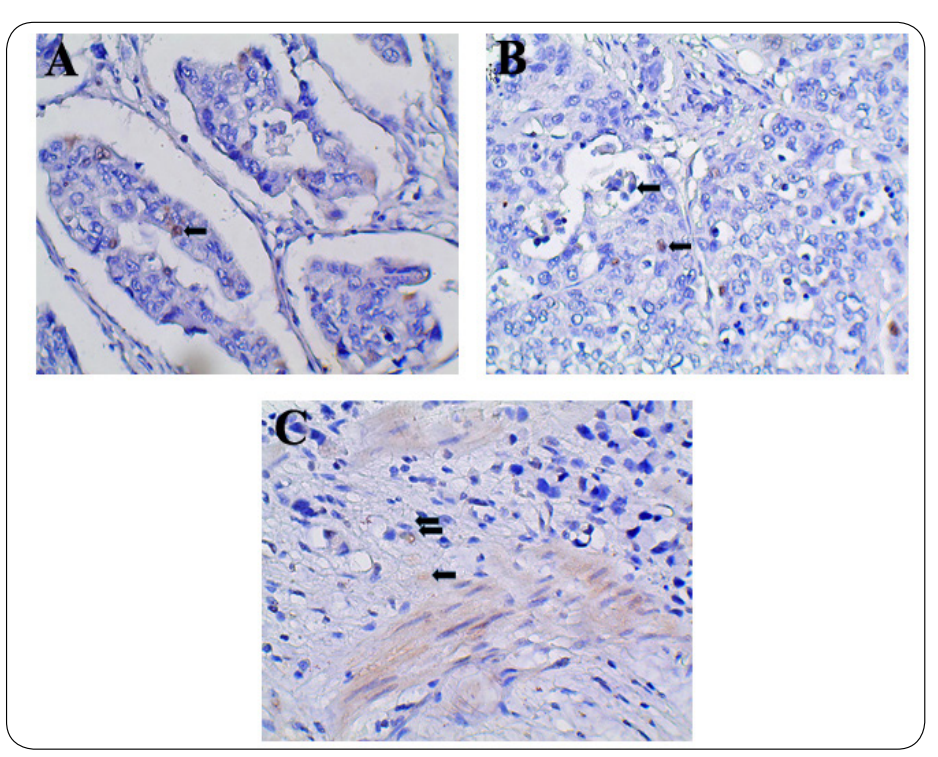

Figure 3: Representative expression of ANG in gastric adenocarcinoma, signet-ring carcinoma and squamous carcinoma (400 X). A. Gastric adenocarcinoma, B. Signetring carcinoma and $C$. Squamous carcinoma. Arrowhead shows nucleus expression in cancerous cells.

\section{ANG expression in different sites of gastric carcinoma}

The expression of ANG in cancer tissues at antrum, fundus body, and cardia was all lower than the adjacent normal tissues, and was mainly detected in the nucleus, less in the cytoplasm, as shown in tables 2 and 3, indicating that lower ANG expression in gastric cancer is not restricted to any particular anatomical sites in the stomach.

\section{ANG expression with tumor grades of gastric carcinoma}

Our results show that there is a significant correlation of tumor grade to ANG expression in the nucleus $(P<$ $0.001)$, but not to that in the cytoplasm $(P=0.3)$.

\section{ANG expression with tumor stages of gastric carcinoma}

Our results also show that there is a significant correlation of gastric carcinoma stages to ANG expression in the nucleus $(P=0.048)$, but not to that in the cytoplasm $(P=0.284)$.

\section{ANG expression with tumor metastasis of gastric carcinoma}

Our results show that there is no significant correlation between tumor invasion and metastasis with ANG 
expression in either nucleus or cytoplasm.

\section{Discussion}

ANG was originally isolated from the conditioned medium of HT-29 human colon adenocarcinoma cells solely based on its angiogenic activity [1]. Subsequently, ANG was found to have a wide tissue distribution with the liver to be the major source of circulating ANG [11]. ANG is the fifth member of the pancreatic ribonuclease (RNase) superfamily with $33 \%$ amino acid identity and $56 \%$ homology to RNase-A, is the prototype family member with no angiogenic activity. The ribonucleolytic activity of ANG is several orders of magnitude lower than that of RNase-A, but this unique ribonucleolytic activity is important for the biological activity [12-15]. Two important structural differences between ANG and RNase-A are responsible for thi feature. The first is that ANG has a receptor binding site comprising of amino acid residues 59 to 68 [16], but RNase-A does not have this site as the corresponding amino acid sequence of this region is very different [17]. Therefore ANG binds to its target cells (including endothelial cells, cancer cells and motor neurons) but RNase-A does not. Another structural difference between ANG and RNase-A is that ANG has a Nuclear Localization Sequence (NLS), whereas RNase-A does not [18]. Therefore ANG undergoes nuclear translocation in its target cells but RNase-A does not. ANG has been shown to undergo nuclear translocation in endothelial cells [18-20], in cancer cells $[5,21]$, and in motor neurons $[5,22,23]$. Upon arriving at the nucleus, ANG accumulates in the nucleolus where ribosome biogenesis takes place. Nuclear ANG has been shown to bind to the promoter region of rDNA [24] and stimulates rRNA transcription [25,26]. Thus, ANG acts as a transcription factor to promote rRNA transcription and protein synthesis directly. The rate-limiting step in ribosome biogenesis is rRNA transcription, which would be an important aspect of growth control. Ribosomes are also important for maintaining normal cell function as proteins are essentially required for all cellular activities. ANG-stimulated rRNA transcription has been shown to be permissive for other angiogenic factors to induce angiogenesis [21]. But in stress condition, ANG will accumulate in cytoplasm to produce tiRNA (tRNAderived, stress-induced small RNA) and inhibit protein translation and promotes the assembly of stress granules (SGs). ANG has been found to promote the formation of SGs when cells are subjected to stresses. ANG has been shown to be responsible for stress-induced cleavage of tRNA and as an effector of stress-induced translational repression and significantly inhibits protein synthesis thereby promoting cell survival $[27,28]$. Recently, ANG has also been shown to play a role in stem cell regulation, promoting hematopoietic regeneration by dichotomously regulating quiescence of stem and progenitor cell proliferation. Niche-secreted ANG, distinctively alters the functional characteristics of primitive hematopoietic stem/progenitor cells (HSPCs) compared with lineagecommitted myeloid-restricted progenitor (MyePro) cells. Specifically, ANG reduces the proliferative capacity of HSPCs while simultaneously increasing proliferation of MyePros by inducing tiRNA generation in HSPCs and rRNA transcription in MyePro cells, leading to respective reduction and increase in protein synthesis. Recombinant ANG protein improves survival of irradiated animals and enhances hematopoietic regeneration of mouse and human HSPCS in transplantation. Thus, ANG plays a non-cell-autonomous role in regulate hematopoiesis by simultaneously preserving HSPC stemness and promoting MyePro proliferation [3].

Many studies suggest that ANG has an important function in tumor growth and proliferation. High levels of ANG have been found in solid tumors, and patients with higher levels of ANG have a poor prognosis [4-9]. ANG in healthy person will vary from $294 \mathrm{ng} / \mathrm{mL}$ to 496 $\mathrm{ng} / \mathrm{mL}$, but in tumor patients it was from $330 \mathrm{ng} / \mathrm{mL}$ to $600 \mathrm{ng} / \mathrm{mL}$, and there was a decrease in the amount of ANG levels in tumors after treatment [29]. However, two studies in breast cancer showed opposite result where high angiogenin levels were associated with a good prognosis in one study [30], and were associated with a poor prognosis in the other [31]. Chen et al. [32] reported that increased expression of angiogenin in gastric carcinoma in correlation with tumor angiogenesis and proliferation, but the ANG expression level had no correlation with the age of patients, location, histological type, lymph node metastasis, and clinical stage of the tumor from 68 operated patients with gastric cancer. Shimoyama and Kaminski [33] reported that increased angiogenin expression in gastric cancer correlated with cancer progression from 21 operated patients with gastric cancer. In our study, we used TMA from 104 operated patients with gastric cancer, by TMA technology avoided dying difference and we used the monoclonal antibody 26-2F donated by Guofu Hu's Lab (whose lab discover ANG 30 years ago and concentrated in ANG research work all along) to provide a more convincible result than before, the discrepancy between ANG expression in gastric cancer tissue may also limit by earlier knowledge of ANG function. 
Table 1: The characteristic of cancer and patient with histological diagnosis.

\begin{tabular}{c|c|c}
\hline Variable & & $\mathbf{N}$ \\
\hline Gender & Male & 77 \\
& Female & 27 \\
\hline Mean age & & $60.3 \pm 9.85$ \\
\hline Gastric Area & Cardia & 40 \\
& Body/Fundus & 36 \\
& Antrum & 28 \\
\hline Histological diagnosis(104) & Adenocarcinoma & 102 \\
& Signet-ring carcinoma & 1 \\
& Squamous carcinoma & 1 \\
\hline Cancer adjacent gastric mucosa(104) & Normal mucosa & 42 \\
& Chronic gastritis & 59 \\
& Atrophic gastritis & 3 \\
\hline
\end{tabular}

Note: Data are presented as mean \pm standard deviation

Table 2: ANG expression in nucleus in patients with different clinicopathological feature.

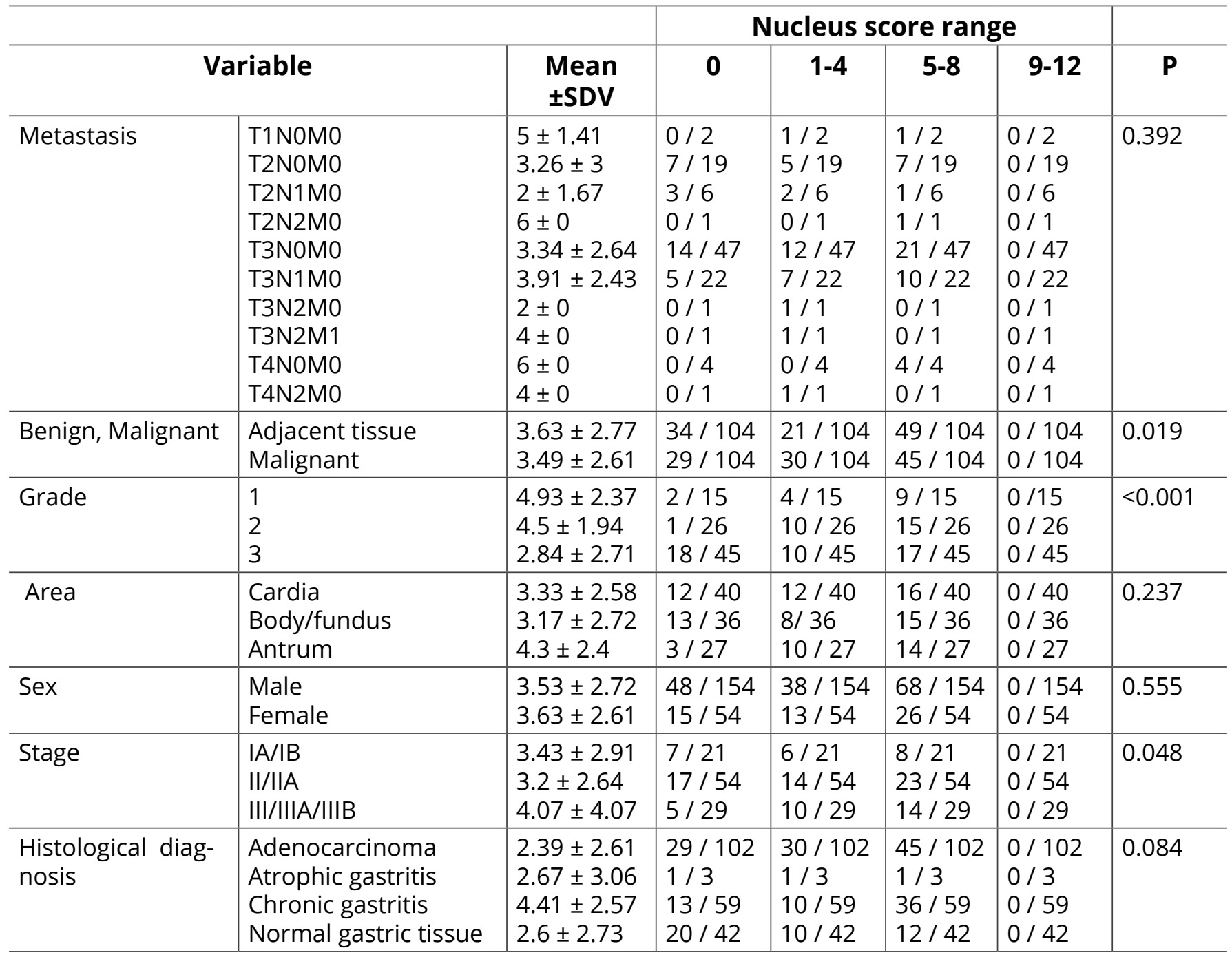

Data are presented as mean \pm standard deviation 
Table 3: ANG expression in cytoplasm in patients with different clinicopathological feature.

\begin{tabular}{|c|c|c|c|c|c|c|c|}
\hline \multirow{2}{*}{\multicolumn{2}{|c|}{ Variable }} & \multirow[b]{3}{*}{\begin{tabular}{l}
\multicolumn{1}{c}{ Mean \pm DV } \\
$5 \pm 1$ \\
$0.68 \pm 1.95$ \\
$0 \pm 0.67$ \\
$0 \pm 0$ \\
$0.36 \pm 1.01$ \\
$0.36 \pm 0.95$ \\
$0 \pm 0$ \\
$0 \pm 0$ \\
$0 \pm 0$ \\
$15 \pm 0$
\end{tabular}} & \multicolumn{4}{|c|}{ Cytoplasm score range } & \multirow[b]{2}{*}{$\mathbf{P}$} \\
\hline & & & 0 & $1-4$ & $5-8$ & $9-12$ & \\
\hline Metastasis & $\begin{array}{l}\text { T1N0M0 } \\
\text { T2N0M0 } \\
\text { T2N1M0 } \\
\text { T2N2M0 } \\
\text { T3N0M0 } \\
\text { T3N1M0 } \\
\text { T3N2M0 } \\
\text { T3N2M1 } \\
\text { T4NOM0 } \\
\text { T4N2M0 }\end{array}$ & & $\begin{array}{l}2 / 2 \\
16 / 19 \\
5 / 6 \\
1 / 1 \\
41 / 47 \\
19 / 22 \\
1 / 1 \\
1 / 1 \\
4 / 4 \\
0 / 1\end{array}$ & $\begin{array}{l}0 / 2 \\
2 / 19 \\
1 / 6 \\
0 / 1 \\
6 / 47 \\
3 / 22 \\
0 / 1 \\
0 / 1 \\
0 / 4 \\
1 / 1\end{array}$ & $\begin{array}{l}0 / 2 \\
1 / 19 \\
0 / 6 \\
0 / 1 \\
0 / 47 \\
0 / 22 \\
0 / 1 \\
0 / 1 \\
0 / 4 \\
0 / 1\end{array}$ & $\begin{array}{l}0 / 2 \\
0 / 19 \\
0 / 6 \\
0 / 1 \\
0 / 47 \\
0 / 22 \\
0 / 1 \\
0 / 1 \\
0 / 4 \\
0 / 1\end{array}$ & 0.85 \\
\hline benign, Malignant & $\begin{array}{l}\text { Adjacent tissue } \\
\text { Malignant }\end{array}$ & $\begin{array}{l}4.31 \pm 3.15 \\
0.43 \pm 1.24 \\
\end{array}$ & $\begin{array}{l}19 / 104 \\
90 / 104 \\
\end{array}$ & $\begin{array}{l}45 / 104 \\
12 / 104 \\
\end{array}$ & $\begin{array}{l}30 / 104 \\
2 / 104 \\
\end{array}$ & $\begin{array}{l}10 / 104 \\
0 / 104 \\
\end{array}$ & $<0.001$ \\
\hline Grade & $\begin{array}{l}1 \\
2 \\
3 \\
\end{array}$ & $\begin{array}{l}0.93 \pm 2.22 \\
0.19 \pm 0.69 \\
0.24 \pm 0.83\end{array}$ & $\begin{array}{l}12 / 15 \\
24 / 26 \\
41 / 45\end{array}$ & $\begin{array}{l}2 / 15 \\
2 / 26 \\
4 / 45 \\
\end{array}$ & $\begin{array}{l}1 / 15 \\
0 / 26 \\
0 / 45\end{array}$ & $\begin{array}{l}0 / 15 \\
0 / 26 \\
0 / 45\end{array}$ & 0.3 \\
\hline Area & $\begin{array}{l}\text { Cardia } \\
\text { Body/fundus } \\
\text { Antrum }\end{array}$ & $\begin{array}{l}0.3 \pm 0.94 \\
0.25 \pm 0.73 \\
0.89 \pm 1.93\end{array}$ & $\begin{array}{l}36 / 40 \\
32 / 36 \\
21 / 27\end{array}$ & $\begin{array}{l}4 / 40 \\
4 / 36 \\
5 / 27 \\
\end{array}$ & $\begin{array}{l}0 / 40 \\
0 / 36 \\
1 / 27\end{array}$ & $\begin{array}{l}0 / 40 \\
0 / 36 \\
0 / 27\end{array}$ & 0.415 \\
\hline Sex & $\begin{array}{l}\text { Male } \\
\text { Female }\end{array}$ & $\begin{array}{l}2.51 \pm 3.17 \\
1.96 \pm 2.77\end{array}$ & $\begin{array}{l}79 / 154 \\
30 / 54\end{array}$ & $\begin{array}{l}40 / 154 \\
18 / 54\end{array}$ & $\begin{array}{l}27 / 154 \\
4 / 54\end{array}$ & $\begin{array}{l}8 / 154 \\
2 / 54 \\
\end{array}$ & 0.275 \\
\hline Stage & $\begin{array}{l}\text { IA/IB } \\
\text { II/IIA } \\
\text { III/IIIA/IIIB }\end{array}$ & $\begin{array}{l}0.62 \pm 1.86 \\
3.90 \pm 1.07 \\
0.38 \pm 0.98 \\
\end{array}$ & $\begin{array}{l}18 / 21 \\
47 / 54 \\
25 / 29\end{array}$ & $\begin{array}{l}2 / 21 \\
7 / 54 \\
4 / 29 \\
\end{array}$ & $\begin{array}{l}1 / 21 \\
0 / 54 \\
0 / 29\end{array}$ & $\begin{array}{l}0 / 21 \\
0 / 54 \\
0 / 29 \\
\end{array}$ & 0.284 \\
\hline $\begin{array}{l}\text { Different } \\
\text { histological pathol- } \\
\text { ogy }\end{array}$ & $\begin{array}{l}\text { Adenocarcinoma } \\
\text { Atrophic gastritis } \\
\text { Chronic gastritis } \\
\text { Normal tissue }\end{array}$ & $\begin{array}{l}0.75 \pm 1.24 \\
3.33 \pm 5.77 \\
4.68 \pm 2.9 \\
3.86 \pm 3.31\end{array}$ & $\begin{array}{l}90 / 102 \\
2 / 3 \\
5 / 59 \\
12 / 42\end{array}$ & $\begin{array}{l}13 / 102 \\
0 / 3 \\
30 / 59 \\
15 / 42\end{array}$ & $\begin{array}{l}1 / 102 \\
0 / 3 \\
18 / 59 \\
10 / 42\end{array}$ & $\begin{array}{l}0 / 102 \\
1 / 3 \\
4 / 59 \\
5 / 42\end{array}$ & $<0.001$ \\
\hline
\end{tabular}

Data are presented as mean \pm standard deviation

\section{Conclusion}

Role of ANG in gastric cancer is not very clear yet. Here our results show that ANG expression in the cytoplasm and nucleus is inversely correlated with gastric malignancy and that ANG expression in the nucleus is inversely correlated with tumor progression of gastric cancer (grades and stages). But neither cytoplasm nor nucleus ANG expression is correlated with tumor metastasis. Thus, ANG may be clinically useful gastric cancer diagnosis and prognosis. An interesting finding was that ANG seems to be expressed in the area where gastric stem cells are situated (gastric basal gland and isthmus) in normal gastric glands. It is therefore plausible that a decrease in ANG expression will affect the repairing function of gastric stem cells and lead to carcinogenesis. We infer that, as ANG expression decrease, gastric stem cells at the base and isthmus undergo more robust apoptosis and exhaustion under stress conditions and therefore impair damage repair leading to cancer initiation and progression. The molecular details by Int Gast Hepatol, 2(1): 137-144 (2019) which ANG is involved in gastric carcinogenesis need to be investigated in the future.

\section{Conflict of interest statement}

The authors declare no conflict

\section{Financial support}

This work was financially supported by the National Major Special Program of China (No. 2012ZX09103101047) and National Natural Science Foundation of China (NSFC, No. 81373873).

\section{References}

1. Fett JW, Strydom DJ, Lobb RR, et al. Isolation and characterization of angiogenin, an angiogenic protein from human carcinoma cells. Biochemistry. 1985;24(20):5480-5486. https://www.ncbi.nlm.nih. gov/pubmed/4074709

2. Wu D, Yu W, Kishikawa H, et al. Angiogenin loss-of- 
function mutations in amyotrophic lateral sclerosis. Ann Neurol. 2007;62(6):609-617. Doi: http://dx.doi. org/10.1002/ana.21221

3. Goncalves KA, Silberstein L, Li S, et al. Angiogenin Promotes Hematopoietic Regeneration by Dichotomously Regulating Quiescence of Stem and Progenitor Cells. Cell. 2016;166(4):894-906. Doi: http://dx.doi.org/10.1016/j.cell.2016.06.042

4. Tello-Montoliu A, Patel JV, Lip GYH. Angiogenin: a review of the pathophysiology and potential clinical applications. J Thromb Haemost. 2006;4(9):18641874. Doi: http://dx.doi.org/10.1111/j.15387836.2006.01995.x

5. Yoshioka N, Wang L, Kishimoto K, Tsuji T, Hu G. A therapeutic target for prostate cancer based on angiogenin-stimulated angiogenesis and cancer cell proliferation. Proc Natl Acad Sci USA. 2006;103(39):14519-14524. Doi: http://dx.doi. org/10.1073/pnas.0606708103

6. Olson KA, Byers HR, Key ME, Fett JW. Prevention of human prostate tumor metastasis in athymic mice by antisense targeting of human angiogenin. Clin Cancer Res. 2001;7(11):3598-3605. http://clincancerres. aacrjournals.org/content/7/11/3598

7. Katona TM, Neubauer BL, Iversen PW, Zhang $\mathrm{S}$, Baldridge LA, Cheng L. Elevated expression of angiogenin in prostate cancer and its precursors. Clin Cancer Res. 2005;11(23):8358-8363. Doi: http://dx.doi. org/10.1158/1078-0432.CCR-05-0962

8. Majumder PK, Yeh JJ, George DJ, et al. Prostate intraepithelial neoplasia induced by prostate restricted Akt activation: the MPAKT model. Proc Natl Acad Sci USA. 2003;100(13):7841-7846. Doi: http:// dx.doi.org/10.1073/pnas.1232229100

9. Olson KA, Byers HR, Key ME, Fett JW. Inhibition of prostate carcinoma establishment and metastatic growth in mice by an antiangiogenin monoclonal antibody. Int J Cancer. 2002;98(6):923-929. https:// www.ncbi.nlm.nih.gov/pubmed/11948474

10. Sayi A, Kohler E, Hitzler I, et al. The CD4+T cell-mediated IFN-gamma response to Helicobacter infection is essential for clearance and determines gastric cancer risk. J Immunol. 2009;182(11):7085-7101. Doi: http:// dx.doi.org/10.4049/jimmunol.0803293

11. Weiner HL, Weiner LH, Swain JL. Tissue distribution and developmental expression of the messenger RNA encoding angiogenin. Science. 1987;237(4812):280282. https://www.ncbi.nlm.nih.gov/pubmed/2440105

12. Shapiro $R$, Vallee BL. Identification of functional Int Gast Hepatol, 2(1): 137-144 (2019) arginines in human angiogenin by site-directed mutagenesis. Biochemistry. 1992;31(49):12477-12485. https://www.ncbi.nlm.nih.gov/pubmed/1281426

13. Shapiro R, Strydom DJ, Olson KA, Vallee BL. Isolation of angiogenin from normal human plasma. Biochemistry. 1987;26(16):5141-5146. https://www.ncbi.nlm.nih. gov/pubmed/3663649

14. Curran TP, Shapiro R, RiordanJF, Vallee BL. Modulation of the activity of angiogenin by mutagenesis at Asp116. Biochim Biophys Acta. 1993;1202(2):281-286. https://www.ncbi.nlm.nih.gov/pubmed/7691185

15. Russo N, Shapiro R, Acharya KR, Riordan JF, Vallee $\mathrm{BL}$. Role of glutamine-117 in the ribonucleolytic activity of human angiogenin. Proc Natl Acad Sci U S A. 1994;91(8):2920-2924. https://www.ncbi.nlm.nih.gov/ pmc/articles/PMC43486/

16. Hallahan TW, Shapiro R, Vallee BL. Dual site model for the organogenic activity of angiogenin. Proc Natl Acad Sci USA. 1991;88(6):2222-2226. https://www.ncbi.nIm. nih.gov/pubmed/2006161

17. Acharya KR, Shapiro R, Riordan JF, Vallee BL. Crystal structure of bovine angiogenin at 1.5-A resolution. Proc Natl Acad Sci U S A. 1995;92(7):2949-2953. https:// www.ncbi.nlm.nih.gov/pmc/articles/PMC42336/

18. Moroianu J, Riordan JF. Nuclear translocation of angiogenin in proliferating endothelial cells is essential to its angiogenic activity. Proc Natl Acad Sci U S A. 1994;91(5):1677-1681. https://www.ncbi.nlm.nih. gov/pmc/articles/PMC43226/

19. Hu G f, Xu C j, Riordan JF. Human angiogenin is rapidly translocated to the nucleus of human umbilical vein endothelial cells and binds to DNA. J Cell Biochem. 2000;76(3):452-462. https://www.ncbi.nlm.nih.gov/ pubmed/10649442

20. Li R, Riordan JF, Hu G. Nuclear translocation of human angiogenin in cultured human umbilical artery endothelial cells is microtubule and lysosome independent. Biochem Biophys Res Commun. 1997;238(2):305-312. https://www.ncbi.nlm.nih.gov/ pubmed/9299500

21. Kishimoto K, Liu S, Tsuji T, Olson KA, Hu G-F. Endogenous angiogenin in endothelial cells is a general requirement for cell proliferation and angiogenesis. Oncogene. 2005;24(3):445-456. Doi: http://dx.doi.org/10.1038/sj.onc.1208223

22. Kieran D, Sebastia J, Greenway MJ, et al. Control of motoneuron survival by angiogenin. I Neurosci. 2008;28(52):14056-14061. Doi: http://dx.doi. org/10.1523/JNEUROSCI.3399-08.2008 
23. Subramanian V, Feng Y. A new role for angiogenin in neurite growth and pathfinding: implications for amyotrophic lateral sclerosis. Hum Mol Genet. 2007;16(12):1445-1453. Doi: http://dx.doi. org/10.1093/hmg/ddm095

24. Xu Z, Tsuji T, Riordan JF, Hu G. Identification and characterization of an angiogenin-binding DNA sequence that stimulates luciferase reporter gene expression. Biochemistry. 2003;42(1):121-128. Doi: http://dx.doi.org/10.1021/bi020465x

25. Tsuji T, Sun $Y$, Kishimoto $K$, et al. Angiogenin is translocated to the nucleus of HeLa cells and is involved in ribosomal RNA transcription and cell proliferation. Cancer Res. 2005;65(4):1352-1360. Doi: http://dx.doi.org/10.1158/0008-5472.CAN-04-2058

26. Xu Z, Tsuji T, Riordan JF, Hu G. The nuclear function of angiogenin in endothelial cells is related to rRNA production. Biochem Biophys Res Commun. 2002;294(2):287-292. Doi: http://dx.doi.org/10.1016/ S0006-291X(02)00479-5

27. Mazroui R, Sukarieh R, Bordeleau $M-E$, et al. Inhibition of ribosome recruitment induces stress granule formation independently of eukaryotic initiation factor 2alpha phosphorylation. $\mathrm{Mol}$ Biol Cell. 2006;17(10):4212-4219. Doi: http://dx.doi. org/10.1091/mbc.e06-04-0318

28. Emara MM, Ivanov $P$, Hickman $T$, et al. Angiogenininduced tRNA-derived stress-induced RNAs promote stress-induced stress granule assembly. J Biol Chem. 2010;285(14):10959-10968. Doi: http://dx.doi. org/10.1074/jbc.M109.077560
29. Li D, Bell J, Brown A, Berry CL. The observation of angiogenin and basic fibroblast growth factor gene expression in human colonic adenocarcinomas, gastric adenocarcinomas, and hepatocellular carcinomas.J Pathol. 1994;172(2):171-175. Doi: http:// dx.doi.org/10.1002/path.1711720203

30. Musolino C, Alonci A, Bellomo G, et al. Levels of soluble angiogenin in chronic myeloid malignancies: clinical implications. Eur J Haematol. 2004;72(6):416-419. Doi: http://dx.doi.org/10.1111/j.1600-0609.2004.00253.x

31. Sheen-Chen SM, Eng HL, Chen WJ, Chou FF, Chen HS. Serum level of angiogenin in breast cancer. Anticancer Res. 2000;20(6C):4769-4771. https://europepmc.org/ abstract/med/11205216

32. Chen Y, Zhang S, Chen Y-P, LinJ-Y. Increased expression of angiogenin in gastric carcinoma in correlation with tumor angiogenesis and proliferation. World J Gastroenterol. 2006;12(32):5135-5139. Doi: http:// dx.doi.org/10.3748/wjg.v12.i32.5135

33. Shimoyama S, Kaminishi M. Increased angiogenin expression in gastric cancer correlated with cancer progression. J Cancer Res Clin Oncol. 2000;126(8):468-474. https://www.ncbi.nlm.nih.gov/ pubmed/10961390

Copyright: (c) Al-sarraf et al. This is an Open Access article distributed under the terms of the Creative Commons Attribution License, which permits unrestricted use, distribution, and reproduction in any medium, provided the original work is properly cited. 